\title{
Carcass Characteristics and Meat Quality of Thai Inheritance Chickens
}

\author{
Nakarin Pripwai ${ }^{1}$, Wiwat Pattanawong ${ }^{2}$, Montri Punyatong ${ }^{3} \&$ Tawatchai Teltathum $^{4}$ \\ ${ }^{1}$ Faculty of Agricultural Technology, Rajabhat Chiangmai University, Chiangmai, Thailand \\ ${ }^{2}$ Faculty of Animal Science and Technology, Maejo University, Chiang Mai, Thailand \\ ${ }^{3}$ Animal Science, School of Agriculture and Natural Resources, University of Phayao, Phayao, Thailand \\ ${ }^{4}$ Chiangmai Livestock Research and Breeding Center, Sanpatong, Chiangmai, Thailand \\ Correspondence: Nakarin Pripwai, Faculty of Agricultural Technology, Rajabhat Chiangmai University, \\ Chiangmai, Thailand. Tel: 66-81-530-7585. E-mail: nakarinpripwai@gmail.com
}

Received: November 15, 2013 Accepted: December 13, 2013 Online Published: January 15, 2014

doi:10.5539/jas.v6n2p182

URL: http://dx.doi.org/10.5539/jas.v6n2p182

\begin{abstract}
Inheritance chickens are important in the developing countries, because of their meat quality. The present study was performed to investigate the effect of genetic background of Baetong, Black-boned, and Praduhangdum chickens. 30 chickens each and 4 replications of the chicken breeds were reared for 14 weeks. 10 chickens of each replication were sampled and analyzed, including carcass characteristics and meat quality as well as Shear's value, water holding capacity, and color of their meat. No different marketable weight and hot carcass weight was found $(\mathrm{P}>0.05)$. Baetong chickens were lower hot carcass yield than Black-boned chickens and Praduhangdum chickens $(\mathrm{P}<0.05)$. Conversely, Baetong chickens were higher structural frame than Black-boned chickens and Praduhangdum chickens $(\mathrm{P}<0.05)$. Black-boned chickens and Praduhangdum chickens were edible portion, and wing yield than Baetong chickens $(\mathrm{P}<0.05)$. Black-boned chickens and Baetong chickens have more leg yield than Praduhangdum chickens $(\mathrm{P}<0.05)$. While, Praduhangdum chickens have more breast yield than the other chickens $(\mathrm{P}<0.05)$. Black-boned breast meat was more Shear's force and Shear's energy than Baetong breast meat and Praduhangdum breast meat $(\mathrm{P}<0.05)$. Black-boned breast meat and skin was darken than Baetong and Praduhangdum breast meat and skin $(\mathrm{P}<0.05)$. Black-boned breast meat was more drip losses than the others $(\mathrm{P}<0.05)$, while being lower cooking losses than the others $(\mathrm{P}<0.05)$. At the typical marketable weight, Black-boned chickens and Praduhangdum chickens have better meat quality compared with the carcass from Baetong chickens.
\end{abstract}

Keywords: Baetong, Black-boned, Praduhangdum, chicken, meat quality

\section{Introduction}

Poultry meat was an important raw material in the recipes of developing countries (Resurreccion, 2004). The consumers preferred color feather and slowing-growing chickens (Rizzi et al., 2007). Additionally, they favored for their chewy texture, color, and flavor of their meat (Wattanachant et al., 2005). Because these are the main attribute to attract consumers to purchase the meat (Yang \& Jiang, 2005) as well as heritage breed in Hong Kong, Southern China, and Japan (Zhao et al., 2012). A Baetong, Black-boned and Praduhangdum chickens are inheritance chicken breed in the southern, northern and central region of Thailand, respectively. They are medium in body size and slow-growing type, and the market of the chicken is rapid development that is becoming popular for meat production over the commercial fast-growing type (Pripwai, 2007). Genetics is a major factor influencing meat quality. The meat quality consists of 3 categories: appearance, physical and chemical (Lawrie, 1985).

These prospects have driven the small and medium entrepreneurs to put an emphasis on the betterment of the genetic selection for efficiency in growth performance and carcass traits of inheritance chicken breeds (Mehaffey et al., 2006; Lopez et al., 2011). An alternative local breed in poultry production system has an important advantage of biodiversity and sustainable agricultural production (Franco et al., 2012). They have more resistant to pathogens and environmental stressors (Rizzi \& Chiericato, 2010). Moreover, they have some distinct features suitable for a niche market serving consumers who prefer chewy texture of chicken meat (Zhao et al., 2012). Little information is known about the productive performances and meat quality of these chickens. Therefore, the aim of the present study was to assess the extent to which carcass characteristics and meat quality to 
investigate the effect of genetic background of three inheritance chicken breeds as well as Baetong, Black-boned, and Praduhangdum chickens.

\section{Materials and Methods}

\subsection{Bird and Management}

This experiment was carried out to the Animal Unit, Faculty of Agricultural Technology, Rajabhat Chiangmai University, Chiang Mai, Thailand. 360-day old chicks were obtained from local commercial hatchery comprising 120 Baetong chicks, 120 Black-boned chicks and 120 Praduhangdum chicks. Each breed was divided into 4 replicates and 30 chicks each. The chicks were randomly placed into $8-\mathrm{m}^{2}$ on solid floor pen with rice hulled-litter material. All birds were raised in open-housed from February to May 2013. Feeder and waterer space met or exceeded recommendations for Standard of Procedure: Broiler Production of Livestock Development Department, Ministry of Agriculture and Co-operative, Thailand. All birds consumed feed in mash form and water on an ad libitum with the same starter, grower and developer diets of the brown egg pullets as defined by Leeson and Summers (2005).

\subsection{Sample Collection}

At 14 weeks of age, after fasting for 12 hours before slaughter, 10 randomly birds of each replication were individually weighted (total of 120 birds), stunted and killed by hand using conventional neck cut for bleeding. Scalding was operated at $60^{\circ} \mathrm{C}$ for 120 seconds and manually eviscerated. Head and shank were removed and weighted. Hot carcass was processed into Thai style retailed cut and weighted including skeletal frame, leg (drumstick with thigh), wing, breast with fillet, liver, gizzard, spleen and heart. Hot carcass percentage was calculated as percentage of live body weight. The weight percentages of the cuts were calculated as percentage of hot carcass weight. Left-side breast muscle and skin were chilled at $4^{\circ} \mathrm{C}$ for 24 hours until analyzed.

\subsection{Muscle Samples Preparation}

Muscle samples were collected from the left side of the pectoralis major for breast meat physical characteristics, such as Shear's value, meat color and water holding capacity. Skin color and breast meat color were measured on the breast skin for 3 replicates, individually.

\subsection{Color Measurement}

Meat color was measured on the external surface of breast muscle, after skin removal using a portable color difference meter (Chin Spec, HP-2132, S/N 110389, China) based on the lightness ( $\left.L^{*}\right)$, redness (a*), yellowness $\left(b^{*}\right)$ system and the external of the removed skin was measured for color. For each reading 3 measurements were performed, and averaged (Mourao et al., 2008).

\subsection{Water Holding Capacity}

Water holding capacity was determined as driplosses and cooking losses (Jaturasitha et al., 2008).

\subsubsection{Drip Losses}

The pectoralis major muscle sample was weighted 24 hours postmortem, wrapped with a sterilized cotton sheet that sample hang over in a vacuum plastic bag, and stored at $4^{\circ} \mathrm{C}$ for 24 hours. After that, the sample was cleaned with sterilized cotton sheet and weighted again. The difference in weight expressed to the drip loss and showed as the percentage of the initial weight (Berri et al., 2008).

\subsubsection{Cooking Loss}

For cooking loss measurements, the muscle was weighted, placed in plastic bags, cooked in the water bath, $80^{\circ} \mathrm{C}$ internal temperatures by inserting the meat thermometers in the thickest portion of each sample for $10 \mathrm{~min}$, left to cool $4^{\circ} \mathrm{C}$ for 12 hours. Cooking loss was calculated as the percentage of the loss weight of the cooked sample (Symeon et al., 2010).

\subsection{Warner-Bratzler Shear Value Determination}

Shear value was determined by using a texture analyzer an HDP/WBV Warner Bratzler blade set with V slot table (TA/XT Analyzer Plus of Stable Micro Systems, Vienna Court, UK). Cooked breast meats were used to determine for shear value. Three adjacent 0.5 inch-diameter parallel to muscle fiber were cut. Samples were cut perpendicularly to the fiber direction. The mode of action was compression start to finish, pre-test speed 10.0 $\mathrm{mm} / \mathrm{Sec}$, test speed $3.0 \mathrm{~mm} / \mathrm{Sec}$, post-test speed $10.0 \mathrm{~mm} / \mathrm{Sec}$, distance target mode $20 \mathrm{~mm}$, data acquisition rate 200 points per second and trigger force $0.04903 \mathrm{~N}$. Data were shown as the maximum force $\left(\mathrm{F}_{\max }\right)$, time of maximum force $\left(\mathrm{T}_{\text {fmax }}\right)$ and time to cut $\left(\mathrm{T}_{\mathrm{fo}}\right)$ that were calculated to Shear energy and firmness energy. 


\subsection{Statistical Analysis}

The parameters were shown as averaged and standard error. Prior to analysis, homogeneity of variance was tested and the normality of the data was verified. A two-way analysis of variance was used to analyze the data. Data on carcass and meat characteristics were determined and compared in a completely randomized design by using the General Linear Model procedure. The mean square error was used to test significant difference. Differences among treatment were separated by Duncan's Multiple Range Tests. Significant difference was based on $\mathrm{P}<0.05$, unless otherwise stated.

\section{Results and Discussion}

In the present study, the influence of genetic lines of Thai Inheritance chickens of the carcass characteristics and meat quality was investigated that were an important factor in buying behavior. Because the genetic line, diets, and age, and especially in sample preparation, instrument, and measurement conditions were differed, the absolute values of the meat quality in this study could not be related to others (Janisch et al., 2011). The influence of the inheritance breeds in various aspects of the overall quality of poultry meat was investigated. The different genetic lines were evident in carcass characteristics and meat quality.

\subsection{Carcass Characteristics}

Summarized data on carcass characteristics of the Thai Indigenous chicken breed including Baetong chickens, Black-boned chickens, and Praduhangdum chickens was shown as Table 1. The Thai Indigenous chicken breed did not affect marketable weight, hot carcass weight, percent of hot carcass weight, head, and shank. Marketable weight, 14 weeks-old, of the Thai Indigenous chicken breed was approximately 1,400 g body weight $(\mathrm{P}>0.05)$ resulting about1,000 g of hot carcass weight $(\mathrm{P}>0.05)$ or about $70 \%$ hot carcass yield $(\mathrm{P}>0.05)$ that was enough served in Thai's life style. These traits are of economic representating the effect of genetics (Zhao et al., 2009). These results were in agreeing with those reported by Zhao et al. (2009), inheritance Beijing-You, a Chinese non-improved line, and by Wang et al. (2009), Gushi chicken, a local chicken in china and popular among Chinese people. Moreover, these results showed higher than previously reported (Jaturasitha et al., 2008). However, expected marketable weight of fast-growing type broiler at 6 weeks, as well as, Arbor Acre, Ross, Cobb and ISA was 2.36-2.46, 2.39-2.47, 2.35-2.37 and 2.26-2.28 kg (Pripwai, 2007) that was more marketable weight than the Thai inheritance breeds and had no difference marketable body weight among the 5 of the strains most commonly used by the poultry industry (Lopez et al., 2011). Hot carcass yield of the Thai Indigenous chickens was similar to Beijing-You chicken (Zhao et al., 2009) and Gushi chicken (Wang et al., 2009), but was lower than Arbor Acre (Zhao et al., 2009). Hot carcass weight of the Thai inheritance breeds was slightly heavier than 85 days of 1957 Athens-Canadian Randombred reared, while, the hot carcass yield was equally 2001 strain fed with 1957 diet (Havenstein et al., 2003). Baetong chickens have significantly more structural frame than Black-boned chickens and Praduhangdum chickens which led to significantly decrease of edible portion. The marketable body weight of Asia's chicken was about 1.4-1.6 kg with 16 weeks reared periods (Zhao et al., 2009; Wang et al., 2009; Jaturasitha et al., 2008; Tang et al., 2009). And these chickens are most often sold as a whole carcass (Janisch et al., 2011).

For edible portion, Black-boned chickens and Baetong chickens were significantly greater leg yield than Praduhangdum chickens. The chickens in the present study were still better leg yield than previous reported (Jaturasitha et al., 2008). Compared with Chinese inherit chicken, the Thai Indigenous chicken was greater in leg and wing yield (Wang et al., 2009; Zhao et al., 2009; Tang et al., 2009). Moreover, this result showed significant differences were obtained in wing yield in Praduhangdum chickens and Black-boned chickens, which were greater than Baetong. Historically, the Thai Indigenous breed was fighting breed that the wings were big enough to fight. Therefore, wing yield of the Thai Indigenous breed was greater than modern commercial broiler breeds and others indigenous breed (Lumpkins et al., 2007; Franco et al., 2012). In addition, wing proportion of slow-growing type and outdoor access broilers was greater than fast-growing type broiler (Fanatico et al., 2005).

For offal yield, Black-boned chickens and Baetong chickens showed greater the percent of gizzard than Praduhangdum chickens $(\mathrm{P}<0.05)$. This result may show the efficiency of digestion, which in turn has a significant influence in carcass yield (Moore et al., 2008), but the marketable weight was not different. It could be explained that Praduhangdum chickens were more efficiency of digestion than Black-boned chicken and Baetong chickens, respectively. Compared with 28-d-old commercial broilers, Ross 308, Ross 708, and Cobb 700 , breast yield and leg yield were not different, while 41-d-old these broiler still lower breast yield and leg yield than the Thai Indigenous chickens (Janisch et al., 2011). These results agree with Sandercock et al. (2009) that fast-growing broiler are higher amounts of breast and thigh meat compared with a layer or traditional chickens. Carcass characteristics were affected by breed and age (Brake et al., 1994), and variability of meat 
quality characteristics is mainly related to genotype and muscle type differences (Tang et al., 2009). Thereof, the results indicated that carcass characteristics depend on the genetic background.

\subsection{Meat Quality}

Meat quality representing texture, color, and water holding capacity of the chickens that can affect consumer preference (Fanatico et al., 2005) were shown in Table 2.

Baetong breast meat and Praduhangdum breast meat was lower shear value $(27.54 \& 28.28 \mathrm{~N})$ than Black-boned breast meat $(36.43 \mathrm{~N})$. While very tender commercialize broiler meat $(<30 \mathrm{~N})$ would be highly acceptable to consumers (Corzo et al., 2009). The significant difference between the genetics could be due to the activities of the muscle (Rizzi et al., 2007). It could be explained that Black-boned chickens expressed more aggressive and alert than Praduhangdum and Baetong chickens. However, these results were tenderer than previously reported in Thai Indigenous chicken (Wattanachant et al., 2005; Jaturasitha et al., 2008). It was showed that Black-boned meat used to braise with herbs in the recipes of the Highlander and the ethnic Chinese than Baetong and Praduhangdum meat that used to cook in Thai recipes. However, breast meat of the Thai Indigenous breeds was tenderer than other rusticity to Galician Indigenous breed of Spain (Franco et al., 2012). On the other hand, the Thai indigenous chicken exhibited greater shear value than rare rusticity of Chinese chickens because of the fiber diameter size. In addition, slow-growing genotypes exhibited higher shear value than fast-growing genotypes, because of an activities (Jaturasitha et al., 2008) and the collagen cross-linking (Tang et al., 2009).

Poultry meat color is a critical criteria for consumer decision. Breast meat should have a pink color when raw (Mehaffey et al., 2006). Qiao et al. (2002) suggested that determined the $L^{*}$ value of deboned breast meat as follows: lighter than normal, $\mathrm{L}^{*}>53$; normal, $48<\mathrm{L}^{*}<51$; darker than normal $\mathrm{L}^{*}<46$. Boulianne and King (1995) stated that the pale fillets had a greater lightness, less redness, greater yellowness, less total pigment, less myoglobin, less iron. While, the dark fillet had greater total pigment, myoglobin, iron, redness and lower lightness and yellowness (Pauline \& King, 1998). And, Pripwai (2007) stated that the visual appearance of Black-boned chicken that was black as well as, beak, tongue, face, comb, claws, shanks, and legs. In this study, the breast meat lightness of Black-boned, Baetong, and Praduhangum chickens were differed $(\mathrm{P}<0.05)$ that agreed with Jaturasitha et al. (2008), the Black-boned was darken breast meat than other Thai Indigenous chickens. Moreover, breast meat yellowness of Baetong chickens displayed lower score than Praduhangdum chicken $(\mathrm{P}<0.05)$ indicating a less deeply pigmented skin (Ponte et al., 2008). While, breast meat yellowness of Baetong chicken displayed higher score $(\mathrm{P}<0.05)$ than Praduhangdum chickens and Black-boned chicken, respectively. Genetics, feeding, and heme pigment influenced on meat and skin color (Fletcher, 1999), in this study, confirmed the presence of genetic background that may be due to myoglobin content in the muscle (Berri et al., 2001). However, polymorphism of melanocortin 1-receptor $(M C 1 R)$ gene may be a potential candidate gene as marker assisted selection affecting the plumage and the skin color trait of chickens (Yang et al., 2008; Liu et al., 2010; Vidal et al., 2010).

Water holding capacity in term of driplosses and cooking losses is important in carcass and further-processed meat product that were resulted to juiciness (Wang et al., 2009) and tenderness (Mehaffey et al., 2006). Poor water-holding capacity will lack juiciness in meat and further-processed products (Fanatico et al., 2005). The breast meat of Praduhangdum chickens had a better water holding capacity accompanied by cooking losses than Baetong chickens $(\mathrm{P}<0.05)$, and Black-boned chickens $(\mathrm{P}<0.05)$, respectively. The breast meat of Black-boned chickens exhibited better drip loss than Baetong chickens $(\mathrm{P}<0.05)$, but they did not differ to Praduhangdum chickens. It may have been that the major part of water in the muscle was bound to the myofibrils or located in the extracellular protein that fluid expelled from these proteins by gravity as a result changed such as shrinkage of the myofibrils and proteolysis of the costameres during driplosses (Janisch et al., 2011). Moreover, the cell structure could be destructed and particularly shrinkage of the connective tissue during the cooking losses (Tornberg, 2005). The driplosses and cooking losses value in this experiment is too high. These results were supported by Kok et al. (2005) that a significant relationship between the cooking loss and the weight of the fillet, which is higher in lower weight of the fillet and by Fanatico et al. (2005) that bigger and thick breast meat did not lose as much water as smaller and thinner breast meat.

\section{Conclusions and Further Investigations}

The results from this study demonstrated differences between Black-boned chickens, Baetong chickens, and Praduhangdum chickens in several indices related to carcass quality. At the typical market weight, the carcass from Black-boned chickens and Praduhangdum chickens was judged to have better quality with regard to carcass yield, edible portion, and meat characteristics compared with the carcass from Baetong chicken. 
For the further investigation, Black-boned chickens and Praduhangdum chickens were basically a non-improved breed and therefore not selected for lean or egg production. They have the potential genetic background becoming popular. However, feeding program under the different stages of growth and environment has received limited consideration that should be further studied due to balance poultry performance, carcass characteristics and quality, and economic yield.

Table 1. Carcass characteristics of Thai Indigenous Chicken ${ }^{1}$

\begin{tabular}{lccc}
\hline \multirow{2}{*}{ Parameter } & \multicolumn{3}{c}{ Breed } \\
\cline { 2 - 4 } & Black-boned & Baetong & Praduhangdum \\
\hline Marketable Weight, g & $1419.73 \pm 19.19$ & $1410.82 \pm 18.28$ & $1376.65 \pm 12.60$ \\
Hot Carcass Wt., g & $986.54 \pm 19.45$ & $938.82 \pm 18.53$ & $970.83 \pm 12.78$ \\
Hot Carcass, \% & $69.41 \pm 0.93^{\mathrm{a}}$ & $66.86 \pm 0.88^{\mathrm{b}}$ & $70.48 \pm 0.61^{\mathrm{a}}$ \\
Skeletal, \% & $36.12 \pm 0.51^{\mathrm{b}}$ & $38.61 \pm 0.49^{\mathrm{a}}$ & $36.51 \pm 0.34^{\mathrm{b}}$ \\
Edible portion, \% & $63.88 \pm 0.51^{\mathrm{a}}$ & $61.39 \pm 0.49^{\mathrm{b}}$ & $63.49 \pm 0.34^{\mathrm{a}}$ \\
$\quad$ Leg & $31.67 \pm 0.52^{\mathrm{a}}$ & $32.13 \pm 0.50^{\mathrm{a}}$ & $30.17 \pm 0.34^{\mathrm{b}}$ \\
Wing & $13.54 \pm 0.23^{\mathrm{a}}$ & $11.85 \pm 0.22^{\mathrm{b}}$ & $13.38 \pm 0.15^{\mathrm{a}}$ \\
Breast & $18.66 \pm 0.48^{\mathrm{b}}$ & $17.40 \pm 0.46^{\mathrm{b}}$ & $19.93 \pm 0.32^{\mathrm{a}}$ \\
Offal, \% & $6.48 \pm 0.27^{\mathrm{a}}$ & $6.64 \pm 0.25^{\mathrm{a}}$ & $5.89 \pm 0.18^{\mathrm{b}}$ \\
Liver & $2.25 \pm 0.08$ & $2.27 \pm 0.07$ & $2.20 \pm 0.05$ \\
Gizzard & $3.37 \pm 0.22^{\mathrm{a}}$ & $3.24 \pm 0.21^{\mathrm{a}}$ & $2.62 \pm 0.14^{\mathrm{b}}$ \\
Spleen & $0.39 \pm 0.10$ & $0.67 \pm 0.09$ & $0.58 \pm 0.06$ \\
Heart & $0.47 \pm 0.02$ & $0.46 \pm 0.02$ & $0.48 \pm 0.01$ \\
\hline
\end{tabular}

${ }^{a, b}$ Values within a row with no common superscript differ significantly $(\mathrm{P}<0.05)$.

${ }^{1} \mathrm{n}=40$ birds per genotype.

Table 2. Meat characteristics for pectoralis major muscle of Thai Indigenous Chicken ${ }^{1}$

\begin{tabular}{lccc}
\hline \multicolumn{1}{c}{ Value } & Black-boned & Baetong & Praduhangdum \\
\hline Shear properties & & & \\
$\mathrm{F}_{\max }, \mathrm{N}$ & $36.43 \pm 2.06^{\mathrm{a}}$ & $27.54 \pm 2.01^{\mathrm{b}}$ & $28.18 \pm 1.34^{\mathrm{b}}$ \\
$\quad$ Shear energy, N-Sec & $28.41 \pm 1.97^{\mathrm{a}}$ & $24.15 \pm 1.92^{\mathrm{b}}$ & $22.37 \pm 1.27^{\mathrm{b}}$ \\
$\quad$ Cohesiveness energy, N-Sec & $1.11 \pm 0.16^{\mathrm{a}}$ & $0.93 \pm 0.15^{\mathrm{ab}}$ & $0.67 \pm 0.10^{\mathrm{b}}$ \\
Color & & & \\
$\quad$ Skin & & & \\
$\quad$ Lightness & $46.70 \pm 1.51^{\mathrm{b}}$ & $53.50 \pm 1.51^{\mathrm{a}}$ & $50.55 \pm 1.48^{\mathrm{ab}}$ \\
$\quad$ Yellowness & $2.49 \pm 0.51^{\mathrm{ab}}$ & $1.81 \pm 0.51^{\mathrm{b}}$ & $3.84 \pm 0.50^{\mathrm{a}}$ \\
Meat & & & \\
$\quad$ Lightness & $50.14 \pm 0.89^{\mathrm{c}}$ & $56.36 \pm 0.89^{\mathrm{b}}$ & $59.44 \pm 0.88^{\mathrm{a}}$ \\
$\quad$ Yellowness & $2.67 \pm 0.80^{\mathrm{c}}$ & $13.53 \pm 0.80^{\mathrm{a}}$ & $5.21 \pm 0.78^{\mathrm{b}}$ \\
Water Holding Capacity & & & \\
$\quad$ Drip & $12.68 \pm 0.58^{\mathrm{a}}$ & $10.44 \pm 0.58^{\mathrm{b}}$ & $11.97 \pm 0.56^{\mathrm{ab}}$ \\
Cooking & $22.18 \pm 0.95^{\mathrm{c}}$ & $29.81 \pm 0.95^{\mathrm{b}}$ & $33.69 \pm 0.93^{\mathrm{a}}$ \\
\hline
\end{tabular}

a,b,c Values within a row with no common superscript differ significantly $(\mathrm{P}<0.05)$.

${ }^{1} \mathrm{n}=40$ birds per genotype.

\section{References}

Beri, C., Wacrenier, N., Millet, N., \& Le Bihan-Duval, E. (2001). Effect of selection for improved body composition on muscle and meat characteristics of broilers from experimental and commercial lines. Poultry Science, 89, 833-838. 
Berri, C., Besnard, J., \& Relandeau, C. (2008). Increasing Dietary Lysine Increases Final pH and Decreases Drip Loss of Broiler Breast Meat. Poultry Science, 87, 480-484. http://www.dx.doi.org/10.3382/ps.2007-00226

Boulianne, M., \& King, A. J. (1995). Biochemical and color characteristics of skinless boneless pale chicken breast. Poultry Science, 74, 1693-1698.

Boulianne, M., \& King, A. J. (1998). Meat color and biochemical characteristics of unacceptable dark-colored broiler chicken carcasses. Journal of Food Science, 63(5), 759-762.

Brake, J., Havenstein, G. B., Ferket, P. R., Rives, D. V., \& Giesbrecht, F. G. (1994). Relationship of sex, strain, and body weights to carcass yield and offal production in turkeys. Poultry Science, 74, 161-168. http://www.dx.doi.org/10.3382/ps.0740161

Corzo, A., Schilling, M. W., Loar II, R. E., Jackson, V., Kin, S., \& Radhakrishnan, V. (2009). The effects of feeding distillers dried grains with solubles on broiler meat quality. Poultry Science, 88, 432-439. http://www.dx.doi.org/10.3382/ps.2008-00406

Fanatico, A. C., Pillai, P. B., Cavitt, L. C., Owens, C. M., \&Emmert, J. L. (2005). Evaluation of Slower-Growing Broiler Genotypes Grown with and Without Outdoor Access: Growth Performance and Carcass Yield. Poultry Science, 84, 1321-1327.

Fletcher, D. L. (1999). Broiler breast meat color variation, pH, and texture. Poultry Science, 78, 1323-1327.

Franco, D., Rois, D., Vázquez, J. A., Purriños, L., González, R., \& Lorenzo, J. M. (2012). Breed effect between Mos rooster (Galician indigenous breed) and Sasso T-44 line and finishing feed effect of commercial fodder or corn. Poultry Science, 91, 487-498. http://www.dx.doi.org/10.3382/ps.2011-01546

Havenstein, G. B., Ferket, P. R., \& Qureshi, M. A. (2003). Carcass Composition and Yield of 1957 Versus 2001 Broilers When Fed Representative 1957 and 2001 Broiler Diets. Poultry Science, 82, 1509-1518.

Janisch, S., Krischek, C., \& Wicke, M. (2011). Color values and other meat quality characteristics of breast muscle collected from 3 broiler genetic lines slaughtered at 2 ages. Poultry Science, 90, 1744-1781. http://www.dx.doi.org/10.3382/ps.2010-01073

Jaturasitha, S., Srikanchai, T., Kreuzer, M., \& Wicke, M. (2008). Differences in Carcass and Meat Characteristics between Chicken Indigenous to Northern Thailand (Black-Boned and Thai Native) and Imported Extensive Breeds (Bresse and Rhode Island Red). Poultry Science, 87, 160-169. http://www.dx.doi.org/10.3382/ps.2006-00398

Kok, S., Van Der Palen, J., \& Hemke, G. (2005). Sensory and chemical/physical characteristics of broiler breast fillets from Brazil, Thailand and The Netherlands. In Proc. XVIIth European Symposium of Qualiy Poultry Meat (pp. 262-265). Doorwerth, The Netherlands WSPA, Beekbergen, The Netherlands.

Lawrie, R. A. (1985). Meat Science (4th ed.). Pergamon press, Oxford, UK.

Leeson, S., \& Summers, J. D. (2005). Commercial Poultry Nutrition (3rd ed.). Nottingham University Press, Nottingham, England.

Liu, W. B., Chen, S. R., Zheng, J. X., Qu, L. J., Xu, G. Y., \& Yang, N. (2010). Developmental phenotypic-genotypic associations of tyrosinase and melanocortin 1 receptor genes with changing profiles in chicken plumage pigmentation. Poultry Science, 89, 1110-1114. http://www.dx.doi.org/10.3382/ps.2010-00628

López, K. P., Schilling, M. W., \& Corzo, A. (2011). Broiler genetic strain and sex effects on meat characteristics. Poultry Science. 90, 1105-1111. http://www.dx.doi.org/10.3382/ps.2010-01154

Lumpkins, B. S., Batal, A. B., \& Baker, D. H. (2007). Variations in the Digestible Sulfur Amino Acid Requirement of Broiler Chickens Due to Sex, Growth Criteria, Rearing Environment, and Processing Yield Characteristics. Poultry Science, 86, 325-330.

Mehaffey, J. M., Pradhan, S. P., Meullenet, J. F., Emmert, J. L., Mckee, S. R., \& Owens, C. M. (2006). Meat quality evaluation of minimally aged broiler breast fillets from five commerciameat 1 genetic strains. Poultry Science, 85, 902-908.

Mourao, J. L., Pinheiro, V. M., Prates, J. A. M., Bessa, R. J. B., Ferreira, L. M. A., Fontes, C. M. G. A., \& Ponte, P. I. P. (2008). Effect of dietary dehydrated pasture and citrus pulp on the performance and meat quality of broiler chicken. Poultry Science, 87, 733-743. http://www.dx.doi.org/10.3382/ps.2007-00411 
Ponte, P. I. P, Prates, J. A. M., Crespo, J. P., Crespo, D. G., Mourao, J. L., Alves, S. P., ... Fontes, C. M. G. A. (2008). Restricting the intake of a cereal-based feed in free-range-pastured poultry: Effects on performance and meat quality. Poultry Science, 87, 2032-2042. http://www.dx.doi.org/10.3382/ps.2007-00522

Pripwai N. (2007). Poultry Production. S Printing Ltd., Chiang Mai, Thailand. [In Thai]

Qiao, M., Fletcher, D. L., Northcutt, J. K., \& Smith, D. P. (2002). The Relationship Between Raw Broiler Breast Meat Color and Composition. Poultry Science, 81, 422-427.

Resurreccion, A. V. A. (2004). Sensory aspects of consumer choices for meat and meat products. Meat Science, 66, 11-20. http://dx.doi.org/10.1016/S0309-1740(03)00021-4

Rizzi, C., \& Chiericato, G. M. (2010). Chemical composition of meat and egg yolk of hybrid and Italian breed hens reared using an organic production sytem. Poultry Science, 89, 1239-1251. http://dx.doi.org/10.3382/ps.2008-00045

Rizzi, C., Marangon, A., \& Chiericato, G. M. (2007). Effect of Genotype on Slaughtering Performance and Meat Physical and Sensory Characteristics of Organic Laying Hens. Poultry Science, 86, 128-135.

Sandercock, D. A., Nute, G. R., \& Hocking, P. M. (2009). Quantifying the effects of genetic selection and genetic variation for body size, carcass composition, and meat quality in the domestic fowl (Gallus domesticus). Poultry Science, 88, 923-931. http://www.dx.doi.org/10.3382/ps.2008-00376

Symeon, G. K., Mantis, F., Bizelis, I., Kominakis, A., \& Rogdakis, E. (2010). Effects of caponization on growth performance, carcass composition, and meat quality of medium growth broilers. Poultry Science, 89, 1481-1489. http://www.dx.doi.org/10.3382/ps.2009-00411

Tang, H., Gong, Y. Z., Wu, C. X., Jiang, J., Wang, Y., \& Li, K. (2009). Variation of meat quality traits among five genotypes of chicken. Poultry Science, 88, 2212-2218. http://www.dx.doi.org/10.3382/ps.2008-00036

Tornberg, E. (2005). Effects of heat on meat proteins-Implications on structure and quality of meat products. Meat Science, 70, 493-508. http://dx.doi.org/10.1016/j.meatsci.2004.11.021

Vidal, O., Viñas, J., \& Pla., C. (2010). Variability of the melanocortin 1 receptor (MC1R) gene explains the segregation of the bronze locus in turkey (Meleagris gallopavo). Poultry Science, 89, 1599-1602. http://www.dx.doi.org/10.3382/ps.2010-00726

Wang, K. H., Shi, S. R., Dou, T. C., \& Sun, H. J. (2009). Effect of a free-range raising system on growth performance, carcass yield, and meat quality of slow-growing chicken. Poultry Science, 88, 2219-2223. http://www.dx.doi.org/10.3382/ps.2008-00423

Wattanachant, S., Benjakul, S., \& Ledward, D. A. (2005). Microstructure and thermal characteristics of Thai indigenous andb roiler chicken muscles. Poultry Science, 84, 328-336.

Yang, N., \& Jiang, R. S. (2005). Recent advances in breeding for quality chickens. World's Poultry Science Journal, 61, 373-381.

Yang, Z. Q., Zhang, Z. R., Xu, M., \& Zhu, Q. (2008). Study on Association of Melanocortin 1-Receptor (MC1R) Mutations with Melanin Trait in Chinese Domestic Chickens. Research Journal of Animal Sciences, 2, 45-49.

Zhao, J. P., Chen, J. L., Zhao, G. P., Zheng, M. Q., Jiang, R. R., \& Wen, J. (2009). Live performance, carcass composition, and blood metabolite responses to dietary nutrient density in two distinct broiler breeds of male chickens. Poultry Science, 88, 2575-2584. http://www.dx.doi.org/10.3382/ps.2009-00245

Zhao, J. P., Zhao, G. P., Jiang, R. R., Zheng, M. Q., Chen, J. L., Liu, R. R., \& Wen, J. (2012). Effects of diet-induced differences in growth rate on metabolic, histological, and meat-quality properties of 2 muscles in male chickens of 2 distinct broiler breeds. Poultry Science, 91, 237-247. http://www.dx.doi.org/10.3382/ps.2011-01667

\section{Copyrights}

Copyright for this article is retained by the author(s), with first publication rights granted to the journal.

This is an open-access article distributed under the terms and conditions of the Creative Commons Attribution license (http://creativecommons.org/licenses/by/3.0/). 